\title{
PENINGKATAN KUALITAS SDM MELALUI KETRAMPILAN IPTEK DAN PEMBUATAN LAPORAN KEUANGAN SEDERHANA DI PAUD FLAMBOYAN BANDUNG
}

\author{
Aneu Kuraesin \\ aneukuraesin@gmail.com \\ Suryaman \\ apip.suryaman@yahoo.com \\ Rukamana \\ rukmana_alan@yahoo.com
}

\section{SEKOLAH TINGGI ILMU EKONOMI EKUITAS}

\begin{abstract}
ABSTRAK
Kegiatan pengabdian ini bertujuan untuk meningkatkan dan mengaplikasikan kemampuan dan keahlian sebagai dosen dalam wujud pemenuhan pengabdian kepada masyarakat sebagai bagian dari kewajiban tridharma perguruan tinggi. Pengabdian ini khususnya diberikan kepada staf dan guru guru di PAUD Flamboyan Kota Bandung. Pengabdian ini diberikan untuk meningkatkan kemampuan Sumber Daya Manusia dibidang Ilmu dan Teknologi di PAUD Flamboyan khususnya penggunaan pemakaian perangkat IT sederhana yang sudah dibuatkan softwarenya dan pembuatan laporan keuangan sederhana. Setelah pengabdian maka dapat disimpulkan bahwa (1) staf dan guru dapat memahami ilmu Teknologi sederhana (2) dapat membuat laporan keuangan sederhana yang baik dan benar.
\end{abstract}

Kata kunci: Ilmu Teknologi, Laporan Keuangan Sederhana.

\section{PENDAHULUAN}

Peningkatan kualitas sumber daya manusia menjadi kebutuhan yang mendesak dalam menghadapi persaingan kerja yang semakin ketat, untuk itu diperlukan usaha yang maksimal dari berbagai pihak. Upaya peningkatan SDM ini tidak hanya wajib dilakukan oleh pemerintah saja, akan tetapi wajib pula dilakukan oleh lembaga-lembaga non pemerintahan dan juga seluruh masyarakat. Pemerintah berupaya meningkatkan kualitas SDM melalui pendidikan, sedangkan lembaga non pemerintah melalui pelatihan untuk meningkatkan keterampilan.
PAUD Flamboyan ini berlokasi di jalan Atlas dalam di sebuah gang yang mayoritas penduduknya berprofesi sebagai pedagang kaki lima, dimana anak-anak di daerah tersebut sehari harinya turut orangtua berjualan disepanjang trotoar. Kebiasaan tinggal dipinggir jalan tersebut menimbulkan dampak yang kurang baik bagi anak-anak tersebut, seperti misalnya untuk menghabiskan waktu anak-anak terbiasa menonton film yang belum layak bagi usianya dari $\mathrm{CD}$ yang dijual orangtuanya, mendengarkan pembicaraan yang belum pantas didengar anak-anak, merokok, dan lain-lain. Berdasarkan permasalahan tersebut maka PAUD ini 
didirikan oleh Ibu Yati dengan tujuan untuk meningkatkan mengajarkan anak-anak untuk mampu bersosialisasi dan memberikan pengetahuan anak mengenai perilaku dan akhlak yang baik sedini mungkin.

Saat ini PAUD Flamboyan mempunyai siswa sebanyak 40 orang. Jumlah siswa yang semakin banyak otomatis menimbulkan masalah khususnya dibidang administrasi perkantoran. Dalam mengelola administrasi saat ini PAUD masih menggunakan cara manual yaitu hanya dengan mencatat dalam buku saja, sehingga sering kali staf dan guru memerlukan waktu cukup lama untuk mencari berkas/file yang mereka perlukan.

Sumber daya manusia yang produktif adalah orang-orang memiliki inovasi untuk meningkatkan keahlian atau keterampilan serta menambah wawasan yang dimilikinya untuk menunjang kinerja, sehingga meningkatkan kualitas dirinya.

Masalah yang dihadapi adalah masih kurangnya kemampuan penggunaan Teknologi Informasi yang terkait dengan pengelolaan adminitrasi perkantoran yang masih dilakukan secara manual.

Solusi yang kami tawarkan sesuai dengan permasalahan yang dialami TKA ini yaitu dengan pemberian peralatan pendukung seperti komputer/laptop, printer dan pelatihan adminsitrasi perkantoran yang mencakup pelatihan MS Word, Excell dan laporan keuangan sederhana. Diharapkan melalui pelatihan ini staf dan guru dapat lebih mudah dalam mengelola administrasi perkantoran.

\section{METODE PELAKSANAAN}

Permasalahan prioritas mitra pengabdian adalah meningkatkan kemampuan dalam administrasi perkantoran. Pelatihan diberikan kepada staf dan guru dengan tujuan agar guru dapat menyampaikannya kembali kepada siswa.
Tim pengabdian mempunyai kesepakatan bersama mitra pengabdian, berupa pemberian pelatihan dalam upaya peningkatan kemampuan dalam menggunakan aplikasi yang bermanfaat dalam administrasi perkantoran sederhana seperti Ms Word, Ms Excel dan juga pembuatan laporan keuangan sederhana. Prosedur pelaksanaan pengabdian di PAUD Flamboyan adalah sebagai berikut:

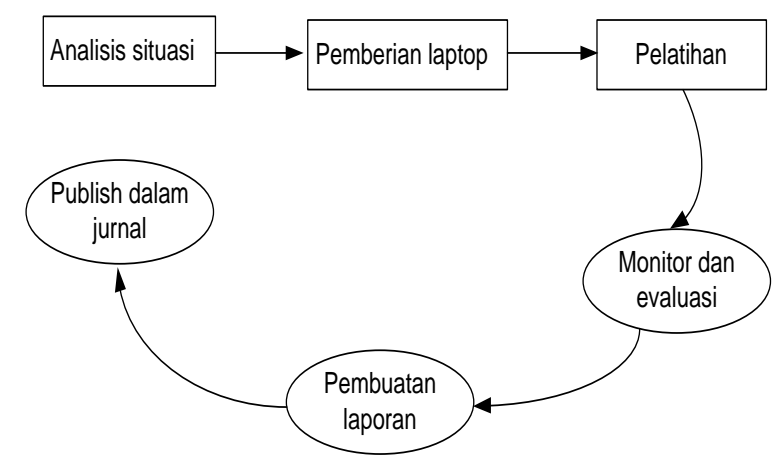

Prosedur Pengabdian di PAUD Flamboyan diuraikan dalam langkah-langkah kegiatan dibawah ini:

1. Analisis Situasi : Pada tahap ini melakukan upaya untuk memetakan permasalahan utama yang terjadi di tempat pengabdian

2. Berdasarkan hasil analisis situasi ternyata diketahui bahwa permasalahan adalah kuranganya ilmu pengetahuan tentang ilmu teknologi dan ketidak sediaan perangkat untuk menunjang pelaksanaan pembelajaran secara interaktif yaitu komputer dalam hal ini berupa pemberian laptop, infocus yang lebih mudah untuk dipindahpindahkan.

3. Pelatihan dilakukan sebagai tahapan berikutnya untuk membantu guru dan staf dalam menggunakan perangkat lunak yaitu pelatihan Microsoft Office khususnya MS Word, MS Excel dan pembuatan laporan keuangan sederhana.

4. Monitor dan Evaluasi adalah tahapan kegiatan pengawasan untuk mengetahui sejauh mana pemberian 
alat dan pelatihan dapat memberi manfaat jangka panjang.

5. Pembuatan laporan pengabdian dilakukan sebagai bukti pelaksanaan pengabdian.

6. Penerbitan kedalam jurnal pengabdian adalah tahapan akhir yang merupakan tujuan akhir dari pengabdian ini.

\section{HASIL PENGABDIAN PADA MASYARAKAT}

\subsection{Hasil}

Hasil yang dicapai dalam pengabdian ini adalah peningkatan kemampuan dari staff, guru dalam mengelola administrasi secara sederhana. Staff dan Guru menjadi lebih paham tentang sistim surat menyurat, pengarsipan, pendokumentasian online, dan penggunaan secara maksimal program Microsoft Word 2010, Microsoft Excel 2010 dan laporan keuangan.

\subsection{Luaran}

Produk yang diberikan dalam pengabdian pada masyarakat ini adalah alat berupa komputer, infokus dan printer. Begitu juga tim pengabdian memberikan pelatihan mengenai administrasi perkantoran termasuk laporan keuangan sederhana. Adapun materi yang diberikan diantaranya:

\section{Mengenal Microsoft Word}

Microsoft Word merupakan program aplikasi pengolah kata (word processor) yang yang biasa digunakan untuk membuat laporan, dokumen berbentuk surat kabar, label surat, membuat tabel pada dokumen. Microsoft Word 2010 merupakan program pengolah kata terbaru dari Microsoft.

2. Mengenal Microsoft Excel

Microsoft Excel merupakan salah satu program spreadsheet yang disediakan oleh Microsoft Corp. Microsoft excel mempunyai banyak fasilitas antara lain kemampuan kalkulasi dengan formula serta fungsi - fungsi aritmatika, statistikdan sebagainya yang kompleks dan fleksibel, fasilitas pengelolaan data base yang sangat mapan, serta kemampuan membuat dan mengelola grafik dengan cepat, mudah dan menarik. Dengan penguasaan exel dasar maka pengguna dapat menggunakan kemampuan exel guna membantu pekerjaan dasar seperti pendataan, pembuatan laporan dsb.Lebih lanjut kemampuan exel dapat digunakan sebagai dasar pengolahan data akuntansi, dapat digambarkan sebagai berikut:

PAUD FLAMBOYAN BANDUNG

LAPORAN LABA RUGI

Des-15

\section{PENERIMAAN :}

SPP

Rp xx

Iuran Komite

$\underline{\operatorname{Rp} x x}$

Total Penerimaan

Rp xxx

\section{PENGELUARAN}

Gaji Guru

$\operatorname{Rp} x x$

Biaya Listrik dan Air $\quad$ Rp xx

Biaya Tranfortasi

Rp xx

Iuran Kegiatan guru

$\operatorname{Rp} x x$

Pembelian ATK

$\operatorname{Rp} x x$

Pembelian Aqua

$\operatorname{Rp} x x$

Total Pengeluaran

$\underline{\operatorname{Rp} x x x}$

Sisa Sebelum Pajak

$\operatorname{Rp} x x x$

Pajak

Rp xxx

Sisa Setelah Pajak

$\operatorname{Rp} \mathbf{x x x}$ 


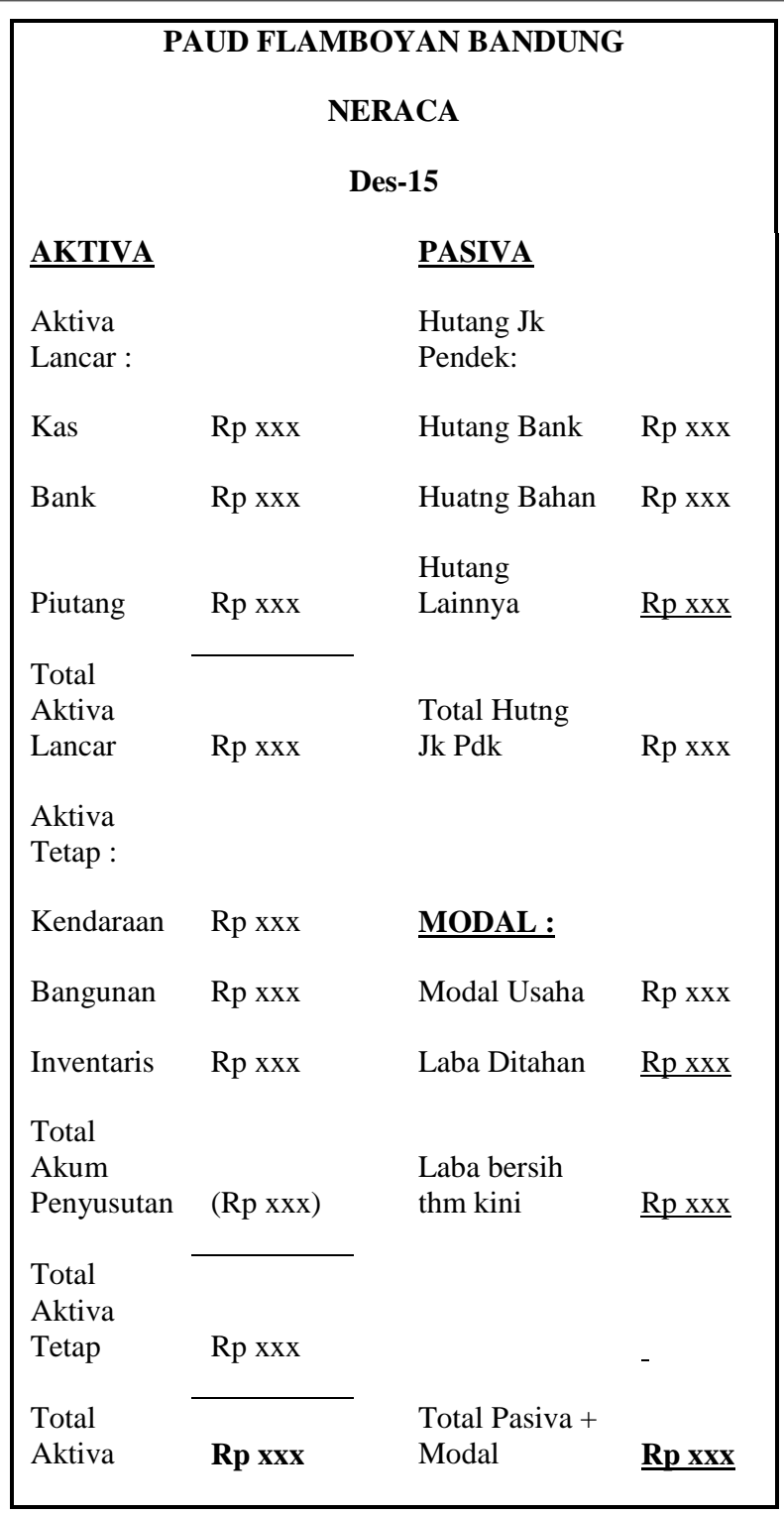

\section{Keterangan :}

Tahapan dalam pembuatan laporan keuangan di PAUD Flamboyan dengan langkah-langkah sederhana diantaranya:

a. Mengumpulkan bukti-bukti transaksi selama tahun buku berjalan. Bukti-bukti yang dikumpulkan berupa kwitansi penerimaan, kwitansi pengeluaran, surat perjanjian wesel, akte dll yang dianggap sebagai bukti transaksi dalam keuangan TK PAUD Flamboyan hal ini tentunya untuk membuktikan kevalidan status dan nilai suatu transaksi.

b. Pembuatan Jurnal. Setelah bukti transaksi dianalisis maka proses selanjutnya membuat jurnal, biasanya setiap ada transaksi maka langsung membuat jurnal hal ini untuk mencegah terjadinya kesalahan pencatatan. Jurnal yang dibuat biasanya dinamakan jurnal umum dengan kolom yang biasa dibuat :

PAUD FLAMBOYAN

JURNAL UMUM

Des-15

\begin{tabular}{|l|c|l|l|l|}
\hline Tanggal & $\begin{array}{c}\text { No } \\
\text { Bukti }\end{array}$ & Keterangan & Debit & Kredit \\
\hline & & & & \\
\hline & & & & \\
\hline
\end{tabular}

c. Posting Ke Buku Besar. Urutan berikutnya setelah memasukan ke jurnal umum adalah memposting ke buku besar. Pungsinya dalah untuk mengelompokkan akun-akun yang ada sesuai dengan jenis transaksinya. Memposting kebuku besar juga mempunyai tujuan untuk menghitung saldo akhir.

\section{PAUD FLAMBOYAN \\ BUKU BESAR}

Des-15

KAS AKUN NO :

\begin{tabular}{|l|l|l|l|l|l|}
\hline TGL & URAIAN & DEBIT & KREDIT & \multicolumn{2}{|c|}{ SALDO } \\
\hline & & & & DEBIT & KREDIT \\
\hline & & & & & \\
\hline
\end{tabular}

d. Neraca percobaan. Neraca percobaan atau disebut juga neraca sebelum penyesuaian. Tujuannya untuk memastikan jenis akun-akun dan saldo normalnya apakah seimbang atau atidaknya antara saldo debit dan saldo kreditnya. 
PAUD FLAMBOYAN

NERACA PERCOBAAN

Des-15

\begin{tabular}{|l|l|l|l|}
\hline TGL & URAIAN & DEBIT & KREDIT \\
\hline & & & \\
\hline & & & \\
\hline
\end{tabular}

e. Jurnal Penyesuaian. Adapun fungsi jurnal penyesuaian adalah untuk mencatat transaksi yang sudah dicatat namun memerlukan koreksi agar nilainya sesuai dengan keadaan yang sebenarnya diakhir peiode akuntansinya.adapun yang harus dibuat jurnal penyesuaian adalah :

1. Perlengkapan. Perlengkapan memerlukan penyesuaian karena danya pemakaian.

2. Beban dibayar dimuka. Beban dibayar dimuka harus dibuat jurnal penyesuaian karena wakt yang telah dijalani/jatuh tempo.

3. Aktiva tetap. Aktiva tetap memerlukan penyesuaian karena da penyusutan.

4. Pendapatan.

Pendapatan memerlukan penyeuaian karena ada pendapatan yang belaum diperhitungkan atau penerimaan yang belum menjadi pendapatan.

5. Beban. Beban memerlukan penyesuaian karena ada beban yang masih harus dibayar atau diperhitungkan sehingga belum menjadi beban.

6. Pendapatan diterima dimuka. Harus ada penyesuaian karena berjalannya waktu atau diserahkannya prestasi pada pelanggan.
PAUD FLAMBOYAN

JURNAL PENYESUAIAN

Des-15

\begin{tabular}{|l|c|l|l|l|}
\hline Tanggal & $\begin{array}{c}\text { No } \\
\text { Bukti }\end{array}$ & Keterangan & Debit & Kredit \\
\hline & & & & \\
\hline & & & & \\
\hline
\end{tabular}

\section{f. Neraca lajur dan Laporan Keuangan.}

Laporan keuangan adalah proses akuntansi yang terpenting. Adapaun laporan keuangan biasanya kalau yang lengkap adalah :

$\rightarrow$ laporan Laba Rugi, yaitu menggambarkan posisi pendapatan dan pengelauran sehingga pada akhirnya diketahui apakah mengalami keuntungan atau kerugian pada periode akuntansinya. $\rightarrow$ Neraca, menggambarkan posisi Aktiva, Pasiva dan Modal. Total Aktiva harus sama dengan total Pasiva Ditambah Modal.

$\rightarrow$ Laporan Arus kas, menggambarkan kas yang masuk dan kas yang keluar dalam periode akuntansinya.

\section{KESIMPULAN}

Setelah pengabdian ini dilaksanakan tim dapat menarik suatu kesimpulan bahwa,

a. Staff dan Guru lebih meningkat kemampuannya dalam ilmu teknologi untuk administrasi.

b. Laporan keuangan untuk PAUD Flamboyan dapat dikerjakan dengan lebih cepat dan tepat.

\section{DAFTAR PUSTAKA}

Maulana, H. (2017). Laporan Keuangan bulanan (artikel). 